\title{
MCM3 Gene
}

National Cancer Institute

\section{Source}

National Cancer Institute. MCM3 Gene. NCI Thesaurus. Code C20377.

This gene is involved in regulation of DNA replication by ensuring that DNA is replicated only once during the cell cycle. It also plays a role in cell proliferation. 